\title{
A novel case report of spinal muscular atrophy with progressive myoclonic epilepsy from Iran [Corrigendum]
}

Shervin Badv R, Nilipour Y, Rahimi-Dehgolan S, RashidiNezhad A, Ghahvechi Akbari M. Int Med Case Rep J. 2019;12:155-159.

We have been advised by an author of this paper that they need to amend a sentence within the main body of the text of this article as the original submitted wording changes the intended meaning.
This error is on page 157 and the sentence "Fortunately, she is alive now and still under therapeutic regimen of the recombinant enzyme." should instead read "Fortunately, she is alive now and under therapeutic regimen of antiepileptic drugs."

\section{Publish your work in this journal}

The International Medical Case Reports Journal is an international, peer-reviewed open-access journal publishing original case reports from all medical specialties. Previously unpublished medical posters are also accepted relating to any area of clinical or preclinical science. Submissions should not normally exceed 2,000 words or 4 published pages including figures, diagrams and references. The manuscript management system is completely online and includes a very quick and fair peer-review system, which is all easy to use. Visit http://www.dovepress.com/testimonials.php to read real quotes from published authors. 